ARTICLE

https://doi.org/10.1038/s41467-019-13985-7

\title{
Precise radiometric age establishes Yarrabubba, Western Australia, as Earth's oldest recognised meteorite impact structure
}

\author{
Timmons M. Erickson (10 1,2,3*, Christopher L. Kirkland (10 ${ }^{4}$, Nicholas E. Timms ${ }^{2}$, Aaron J. Cavosie ${ }^{2}$ \& \\ Thomas M. Davison (1) ${ }^{5}$
}

The $70 \mathrm{~km}$-diameter Yarrabubba impact structure in Western Australia is regarded as among Earth's oldest, but has hitherto lacked precise age constraints. Here we present U-Pb ages for impact-driven shock-recrystallised accessory minerals. Shock-recrystallised monazite yields a precise impact age of $2229 \pm 5 \mathrm{Ma}$, coeval with shock-reset zircon. This result establishes Yarrabubba as the oldest recognised meteorite impact structure on Earth, extending the terrestrial cratering record back >200 million years. The age of Yarrabubba coincides, within uncertainty, with temporal constraint for the youngest Palaeoproterozoic glacial deposits, the Rietfontein diamictite in South Africa. Numerical impact simulations indicate that a $70 \mathrm{~km}$-diameter crater into a continental glacier could release between $8.7 \times 10^{13}$ to $5.0 \times 10^{15} \mathrm{~kg}$ of $\mathrm{H}_{2} \mathrm{O}$ vapour instantaneously into the atmosphere. These results provide new estimates of impact-produced $\mathrm{H}_{2} \mathrm{O}$ vapour abundances for models investigating termination of the Paleoproterozoic glaciations, and highlight the possible role of impact cratering in modifying Earth's climate.

\footnotetext{
${ }^{1}$ Jacobs-JETS, Astromaterials Research and Exploration Science Division, NASA Johnson Space Center, 2101 NASA Parkway, Houston, TX 77058, USA.

${ }^{2}$ The Institute for Geoscience Research (TIGeR), Space Science and Technology Centre, School of Earth and Planetary Sciences, Curtin University, GPO Box 1984, Perth, WA 6845, Australia. ${ }^{3}$ Center for Lunar Science and Exploration, Lunar and Planetary Institute, Universities Space Research Association, 3600 Bay Area Blvd, Houston, TX 77058, USA. ${ }^{4}$ The Institute for Geoscience Research (TIGeR), Centre for Exploration Targeting-Curtin Node, School of Earth and Planetary Sciences, Curtin University, GPO Box 1984, Perth, WA 6845, Australia. ${ }^{5}$ Impacts and Astromaterials Research Centre, Department of Earth Science and Engineering, Imperial College London, London SW7 2AZ, UK. *email: Timmons.M.Erickson@nasa.gov
} 


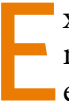
xtraterrestrial bombardment flux is speculated to have had major consequences for the development of Earth's surface environment ${ }^{1,2}$. However, the terrestrial impact record is fragmentary, principally due to tectonics and erosion ${ }^{3,4}$, and is progressively erased into the geologic past when, conversely, the bombardment rate was larger than today ${ }^{5}$. The oldest record of impacts on Earth are Archaean to Palaeoproterozoic ejecta deposits found within the Kaapvaal craton of southern Africa and the Pilbara Craton in Western Australia, spanning ca. 3470 (ref. ${ }^{6}$ ) to $2460 \mathrm{Ma}^{7}$; however, no corresponding impact craters have been identified. Currently only two precisely dated Precambrian-age impact structures are known, the $2023 \pm 4 \mathrm{Ma}$, $>250 \mathrm{~km}$ Vredefort Dome in South Africa ${ }^{8,9}$, and the $1850 \pm 1$ $\mathrm{Ma},>200 \mathrm{~km}$ Sudbury structure in Canada ${ }^{10}$. Other purported Palaeoproterozoic-age impact structures have either poorly constrained ages ${ }^{11}$ or highly contentious impact evidence ${ }^{12,13}$.

A consequence of the incomplete terrestrial impact record is that connections between impact events and punctuated changes to the atmosphere, oceans, lithosphere, and life remain difficult to establish, with the notable exception of the Cretaceous-Paleogene impact $^{14,15}$. Hitherto, the impact cratering record was absent from 2.5-2.1 Ga, when significant changes in the Earth's hydrosphere and atmosphere occurred ${ }^{16,17}$.

Yarrabubba is a recognised impact structure located within the Murchison Domain of the Archaean granite-greenstone Yilgarn Craton of Western Australia (Fig. 1) ${ }^{18}$. No circular crater remains at Yarrabubba; however, the structure has an elliptical aeromagnetic anomaly consisting of an even, low total magnetic intensity domain, measuring approximately $20 \mathrm{~km} \mathrm{~N}-\mathrm{S}$ by $11 \mathrm{~km}$ E-W (Fig. 1) ${ }^{18}$. The present day exposure represents a deep erosional level, as neither impact breccias nor topographic expressions of the over-turned rim or central uplift are preserved. Therefore, the $\sim 20 \mathrm{~km}$ diameter magnetic anomaly has been interpreted to represent the remnant of the deeply buried central uplift of the structure, which is consistent with an original crater diameter of $70 \mathrm{~km}^{18,19}$. Unshocked dolerite dykes formed during either ca. $1200 \mathrm{Ma}$ Muggamurra $^{20}$ or ca. $1075 \mathrm{Ma}$ Warakurna ${ }^{21}$ regional volcanism cross-cut the elliptical magnetic anomaly and thus post-date the impact event.

The main target rocks at the Yarrabubba structure are granitoids collectively known as the Yarrabubba monzogranite (Fig. 1). Identification of shocked quartz and shatter cones in the Yarrabubba monzogranite confirmed an impact origin for the structure $^{18,22}$. The structure is centred on a large exposure of granophyre known locally as Barlangi Rock (Fig. $1 ; 118^{\circ} 50^{\prime} \mathrm{E}$, $27^{\circ} 10^{\prime} \mathrm{S}$ ). Barlangi granophyre is a sodic rhyolite ${ }^{22}$ that has been interpreted as an impact-generated melt rock $^{18}$, radiating dykelike apophyses of granophyre outcrop as far as $3 \mathrm{~km}$ from the centre of the structure. The Barlangi granophyre has thus been interpreted to have intruded into the Yarrabubba monzogranite along faults rather than forming a flat-lying, crater-filling melt sheet, similar to metanorite dykes and apophyses interpreted as impact melt that are exposed in the core of the deeply eroded Vredefort impact structure ${ }^{23}$.

The age of the Yarrabubba impact structure was previously constrained only to be younger than the $2650 \pm 10$ Ma Yarrabubba monzogranite ${ }^{24}$ and older than the ca. $1200-1075 \mathrm{Ma}$ cross-cutting dolerite dykes. Zircon crystals from the Barlangi granophyre have previously yielded a complex age spectrum that span nearly $500 \mathrm{Myr}$, from 2.79 to $2.23 \mathrm{Ga}^{24,25}$. Pseudotachylite veins at Yarrabubba yield a sericite ${ }^{39} \mathrm{Ar} /{ }^{40} \mathrm{Ar}$ age of ca. $1.13 \mathrm{Ga}^{26}$, which likely records alteration during younger mafic volcanism.

This study utilises targeted in situ $\mathrm{U}-\mathrm{Pb}$ geochronology by secondary ion mass spectrometry (SIMS) to analyse recrystallised domains (neoblasts) in monazite and zircon, which have been shown to yield precise ages for ancient impact events ${ }^{27-29}$. We

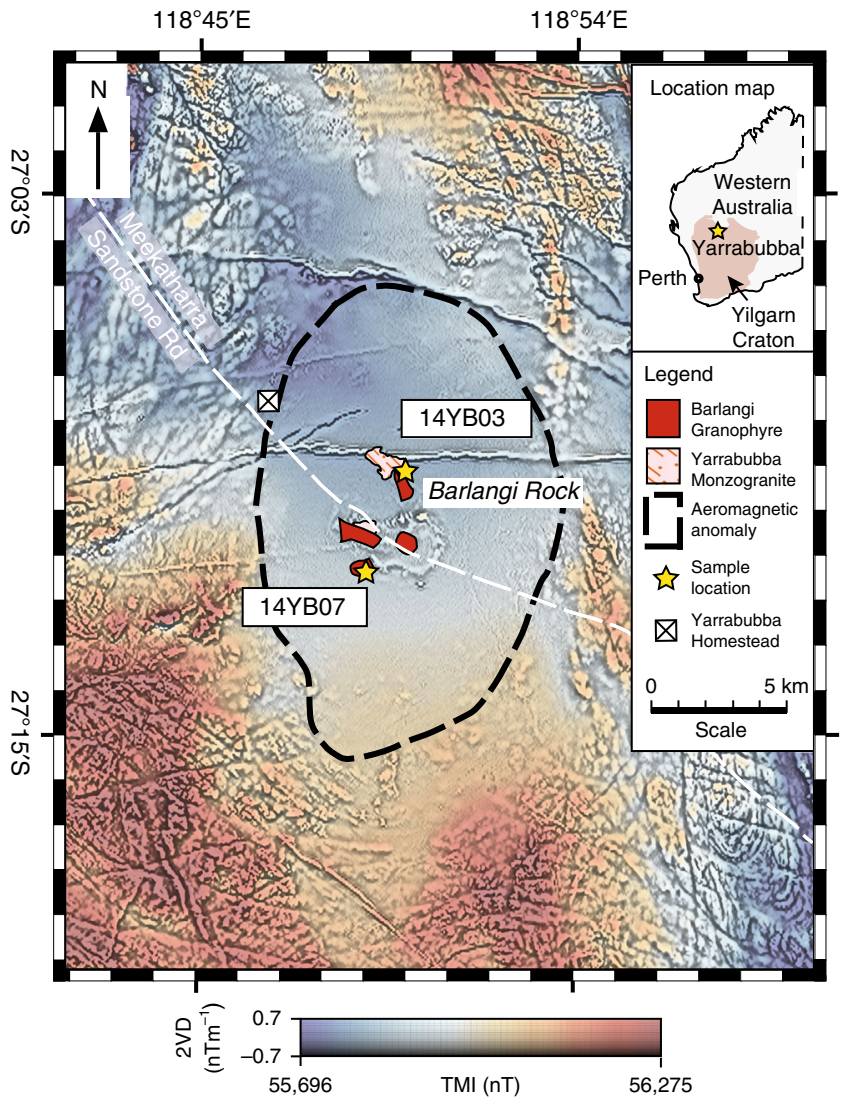

Fig. 1 Map of the Yarrabubba impact structure and sample localities. Composite aeromagnetic anomaly map of the Yarrabubba impact structure within the Yilgarn Craton, Western Australia, showing the locations of key outcrops and samples used in this study. The image combines the total magnetic intensity ( $T M I$, cool to warm colours) with the second vertical derivative of the total magnetic intensity (2VD, greyscale) data ${ }^{81}$. The demagnetised anomaly centred on the outcrops of the Barlangi granophyre is considered to be the eroded remnant of the central uplift domain, which forms the basis of the crater diameter of $70 \mathrm{~km}^{18}$. Prominent, narrow linear anomalies that cross-cut the demagnetised zone with broadly east-west orientations are mafic dykes that post-date the impact structure.

present high-resolution orientation mapping and correlated in situ $\mathrm{U}-\mathrm{Pb}$ analysis to investigate the microstructure and age of shock features in zircon and monazite in target rock and impact melt from the Yarrabubba structure in Western Australia. These results establish Yarrabubba as the oldest preserved impact structure on Earth.

\section{Results and discussion}

Zircon and monazite shock microstructures. Within the Yarrabubba monzogranite, zircon and monazite grains preserve a range of impact-related microstructures. Zircon displays primary igneous growth zoning that is cross-cut by planar and subplanar shock microstructures, including $\{112\}$ shock twins and $\{100\}$ planar deformation bands (Fig. 2a; Supplementary Fig. 1) ${ }^{30-32}$. Monazite preserves a broader range of impact-related textures including domains with low-angle subgrain boundaries and multiple sets of shock twins along (001), (100) and (101), and domains of strainfree neoblasts (Fig. 2b; Supplementary Fig. 2) ${ }^{28,33}$.

In Barlangi granophyre, zircon textures range from unshocked grains preserving primary igneous growth zoning, to grains containing clear evidence of impact metamorphism, such as planar microstructures, polycrystalline aggregates and grains with $\mathrm{ZrO}_{2}$ inclusions (Fig. 2c; Supplementary Fig. 3) ${ }^{34}$. Neoblasts 


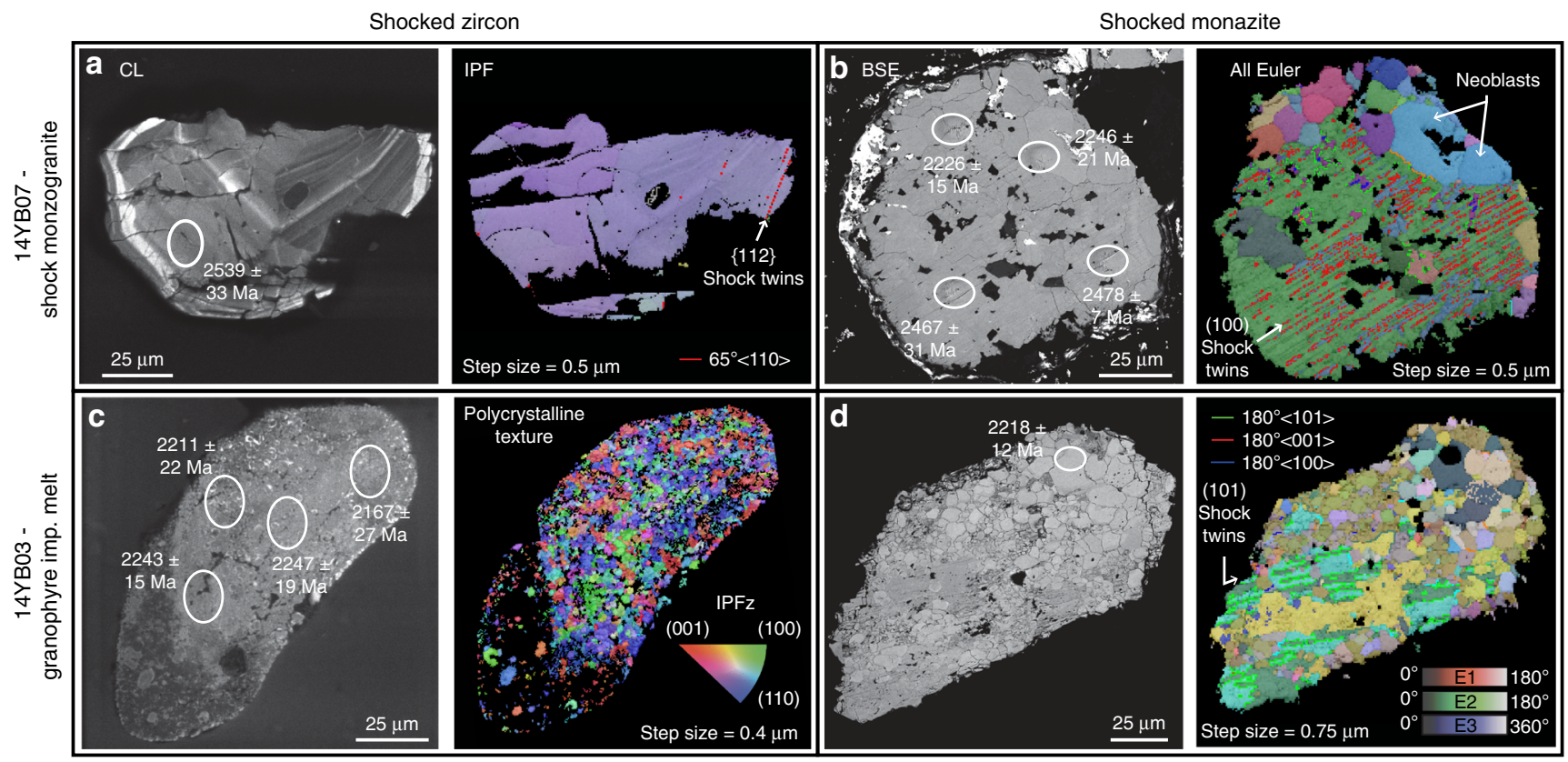

Fig. 2 Monazite and zircon shock recrystallisation textures. Examples of shocked zircon and monazite grains from Yarrabubba monzogranite sample 14 YB07 and Barlangi granophyre impact melt sample 14YB03. a Cathodoluminescence (CL) and Inverse Pole Figure (IPF) images of a shocked zircon with $\{112\}$ deformation twins. The zircon contains primary oscillatory zoning that is cross-cut by shock deformation twins and subplanar low-angle grain boundaries. b Backscattered electron (BSE) image and electron backscatter diffraction (EBSD) all Euler map of a shocked monazite with systematic shock twin domains that are overprinted by neoblasts. $\mathbf{c} C L$ and IPF images of a polycrystalline shocked zircon grain from the granophyric impact melt. Note that individual crystallites exhibit concentric $\mathrm{CL}$ zonation patterns while the overall $\mathrm{CL}$ pattern reflects the original zonation of the grain with a $\mathrm{CL}$ brighter core to $\mathrm{CL}$ dark rim. The IPF orientation map of the zircon is dominantly blue to pink and many of the granules have systematic grain boundaries of either $65^{\circ} /$ $<110>$ or $90^{\circ} /<110>$. d BSE image and all Euler map of shock-deformed monazite displaying highly deformed and twinned domains that are overprinted by neoblasts, from the Barlangi granophyre. Location of U-Pb SIMS analytical spots are denoted on each grain with the ${ }^{207} \mathrm{~Pb} /{ }^{206} \mathrm{~Pb}$ age and $2 \sigma$ errors in $\mathrm{Ma}$.

within polycrystalline zircon aggregates contain systematic misorientation relationships with one another of either $65^{\circ}$ about $<110\rangle$ or $90^{\circ}$ about $\left.<110\right\rangle$, which can only be caused by recrystallisation after formation of $\{112\}$ twins and the highpressure polymorph reidite, respectively, and are unambiguous indicators of shock metamorphism ${ }^{34-36}$. While the $\mathrm{ZrO}_{2}$ inclusions index as baddeleyite (monoclinic- $\mathrm{ZrO}_{2}$ ), crystallographic orientation relationships among transformation twins demonstrate they originally formed from tetragonal- $\mathrm{ZrO}_{2}$ parent grains ${ }^{37}$. Thermal dissociation of zircon to tetragonal- $\mathrm{ZrO}_{2}$ only occurs in silica-saturated melts above $1673^{\circ} \mathrm{C}^{34}$, unequivocally indicating the Barlangi granophyre was a super-heated impact melt. Monazite grains in Barlangi granophyre preserve a similar range of impact-related features to those from Yarrabubba monzogranite, including crystal-plastic strain, deformation twins diagnostic of shock conditions, and strain-free neoblastic domains (Fig. 2d; Supplementary Fig. 4).

Shocked zircon and monazite $\mathrm{U}-\mathrm{Pb}$ results. The $\mathrm{U}-\mathrm{Pb}$ SIMS analyses of zircon from the Yarrabubba monzogranite define a regression, which intercepts concordia at $2626 \pm 36$ and $1202 \pm$ $210 \mathrm{Ma}$ (mean square weight of deviates $[\mathrm{MSWD}]=1.8$; Supplementary Table 1). The upper intercept is interpreted as the primary magmatic crystallisation age of the target rocks, which is within uncertainty of the $2650 \pm 20 \mathrm{Ma}(n=6)$ age obtained previously ${ }^{24}$. The lower intercept age is attributed to partial resetting associated with post-impact dolerite intrusion in the Mesoproterozoic ${ }^{20,21}$. Monazite ${ }^{207} \mathrm{~Pb} /{ }^{206} \mathrm{~Pb}$ ages from Yarrabubba monzogranite yield a bimodal distribution. Analytical spots from the high-strain shocked host and/or twin domains are variably discordant and record ${ }^{207} \mathrm{~Pb} /{ }^{206} \mathrm{~Pb}$ ages from $2478 \pm 14$ to $2323 \pm 16 \mathrm{Ma}$ (Fig. 3a, Supplementary Table 2). These ages may represent either formation during a post-crystallisation metamorphic event or partial radiogenic Pb-loss during the impact event or a subsequent thermal event. In contrast, spots from low-strain, randomly oriented neoblasts cluster around concordia, and have a weighted mean ${ }^{207} \mathrm{~Pb} /{ }^{206} \mathrm{~Pb}$ age of $2227 \pm$ $5 \mathrm{Ma}(n=12, \mathrm{MSWD}=0.89)$ (Fig. $3 \mathrm{~b})$.

Barlangi granophyre zircon ${ }^{207} \mathrm{~Pb} / 206 \mathrm{~Pb}$ ages also show a bimodal age distribution. We interpret the oscillatory-zoned cores with apparent ages of $2781 \pm 14$ to $2319 \pm 28 \mathrm{Ma}$ to represent inherited (pre-impact) zircon grains that were incorporated into the Barlangi granophyre as xenocrysts, consistent with zircon ages determined previously 24,25 . These results indicate the presence of a significant source component in the Barlangi granophyre that predates the $2.65 \mathrm{Ga}$ Yarrabubba monzogranite. Individual analyses from polycrystalline zircon domains are variably discordant and yield ${ }^{207} \mathrm{~Pb} /{ }^{206} \mathrm{~Pb}$ ages from $2259 \pm 30$ to $2156 \pm 52 \mathrm{Ma}$ (Supplementary Table 1). We interpret the data array (Fig. 3a) to be a function of near-recent $\mathrm{Pb}$-loss resulting from exposure to surface fluids. The data array from recrystallised zircon domains yields an upper intercept age of $2246 \pm 17 \mathrm{Ma}$ $(n=13, \mathrm{MSWD}=1.2)$, and two rim analyses with baddeleyite intergrowths are collinear with this regression. We interpret the upper intercept to reflect both new zircon growth and near complete resetting of $\mathrm{U}-\mathrm{Pb}$ systematics in pre-existing domains during shock metamorphism. This date is within uncertainty of a single previously reported $\mathrm{U}-\mathrm{Pb}$ zircon analysis from the Barlangi granophyre of $2234 \pm 28 \mathrm{Ma}^{24}$, which was inferred to indicate a Palaeoproterozoic impact age $\mathrm{e}^{18}$.

Barlangi granophyre monazite ${ }^{207} \mathrm{~Pb} /{ }^{206} \mathrm{~Pb}$ ages preserve a bimodal distribution similar to monazite from Yarrabubba monzogranite. Analyses from the highly strained host and 

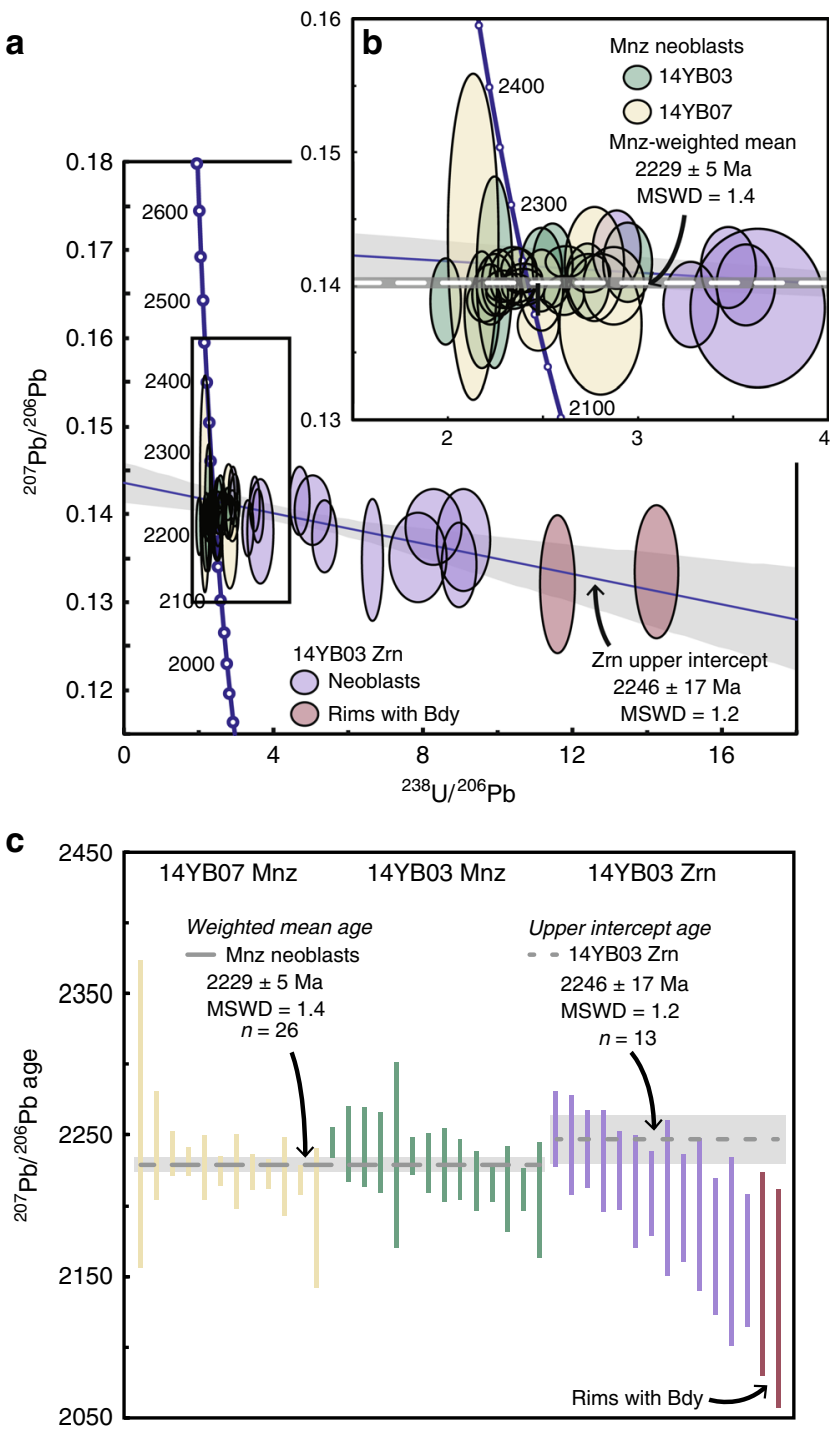

Fig. 3 Shock-recrystallised zircon and monazite age spectra. a Zircon ( $\mathrm{rn}$ ) and monazite (Mnz) U-Pb Tera-Wasserburg concordia plot of shockrecrystallised zircon and monazite neoblasts from the Barlangi granophyre and the Yarrabubba monzogranite. Monazite analyses from the Yarrabubba monzogranite are coloured yellow, monazite analyses from the Barlangi granophyre are coloured green, neoblastic zircon analyses from the granophyre are blue and analyses from zircon rims with baddeleyite (Bdy) intergrowths are maroon. While all zircon neoblastic domains show variable Pb-loss, the analyses form a linear discordia to ca. $2240 \mathrm{Ma}$, interpreted as the impact age. $\mathbf{b}$ All monazite neoblasts record a weighted mean ${ }^{207} \mathrm{~Pb} /{ }^{206} \mathrm{~Pb}$ age of $2229 \pm 5 \mathrm{Ma}$ (horizontal red bar). c Weighted mean ${ }^{207} \mathrm{~Pb} /{ }^{206} \mathrm{~Pb}$ age plot of the neoblastic domains from monazite grains of the shock-deformed Yarrabubba monzogranite (yellow), monazite from the Barlangi granophyre (green) and zircon from the granophyre (blue). Note overlap of weighted mean age from each monazite population, supporting the interpretation of $2229 \pm 5 \mathrm{Ma}$ as the impact age. All error ellipses and bars are reported at the $2 \sigma$ level.

twinned domains display variable normal and reverse discordance and record $207 \mathrm{~Pb} / 206 \mathrm{~Pb}$ ages between $2457 \pm 24$ and $2284 \pm 14 \mathrm{Ma}$. In contrast, analyses from low-strain, randomly oriented neoblasts cluster around concordia, with a weighted mean ${ }^{207} \mathrm{~Pb} / 206 \mathrm{~Pb}$ age of $2231 \pm 8 \mathrm{Ma} \quad(n=14$, MSWD = 1.9) (Fig. 3b; Supplementary Table 2).

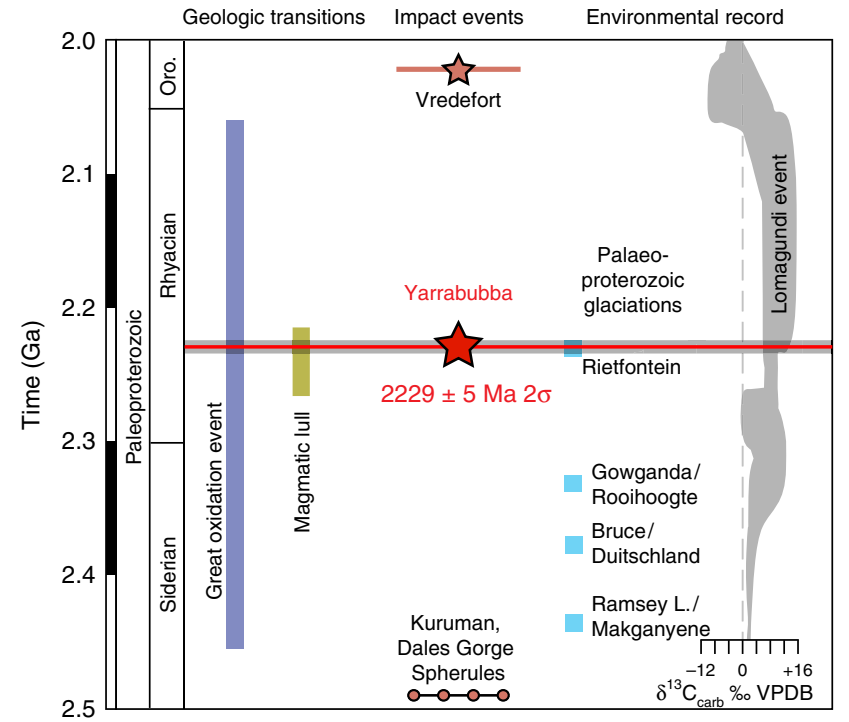

Fig. 4 Temporal evolution of the early Palaeoproterozoic Earth. Key features include the Yarrabubba and other impact events, the Great Oxidation Event (2.06-2.45 Ga) and glaciations (2.23-2.54 Ga). Glacial deposition age constraints from ref. ${ }^{38}$, the global $\delta^{13} \mathrm{C}$ trend of carbonates is modified from ref. ${ }^{51}$, and the lull in magmatic activity is modified from ref. ${ }^{44}$. Note the close association of the Yarrabubba impact event to the end of the final Palaeoproterozoic glaciation, the Rietfontein, at $2225 \pm 3 \mathrm{Ma}$ and followed by the large positive $\delta^{13} \mathrm{C}$ excursion known as the Lomagundi event 82,83 . Other impacts include the $2.02 \mathrm{Ga}$ Vredefort Dome ${ }^{8}$, and the $2.49 \mathrm{Ga}$ correlated Kuruman spherule layer in the Griqualand West basin of South Africa and the Dales Gorge spherule layer of the Hamersley basin in Western Australia7.

When combined, all neoblastic monazite domains from both Barlangi granophyre and Yarrabubba monzogranite define a cluster centred on concordia (Fig. 3a) and yield a weighted mean ${ }^{207} \mathrm{~Pb} / 206 \mathrm{~Pb}$ age of $2229 \pm 5 \mathrm{Ma}(n=26, \mathrm{MSWD}=1.4$, Fig. $3 \mathrm{c})$, which we interpret to record monazite recrystallisation during shock metamorphism and the best estimate of the Yarrabubba impact event (Fig. 3). The weighted mean ${ }^{207} \mathrm{~Pb} /{ }^{206} \mathrm{~Pb}$ age for neoblastic zircon of $2246 \pm 17 \mathrm{Ma}(n=13$, MSWD $=1.2)$ overlaps with the monazite age, but is less precise. The new Yarrabubba impact age of $2229 \pm 5 \mathrm{Ma}$ determined here extends the terrestrial record of impact craters by 200 million years $^{8}$, and demonstrates the potential for discovery of ancient impact structures on Archaean cratons.

Implications for the Palaeoproterozoic Earth. The age constraints presented here establish Yarrabubba as the first recognised meteorite impact to have occurred during the Rhyacian period, a dynamic time in the evolution of Earth following the transition from the Archaean to the Proterozoic eon. At least four glacial diamictite deposits, three of which are found on multiple cratons, are recognised between 2.4 and $2.2 \mathrm{Ga}^{38}$. Of these deposits, the $>2.42 \mathrm{Ga}$ Makganyene diamictite from the Kaapvaal craton of southern Africa has been interpreted to represent lowlatitude glaciers that may signify global ice conditions ${ }^{39}$. The youngest Palaeoproterozoic glacial deposit, the Rietfontein diamictite within the Transvaal basin of South Africa, has a minimum depositional age of $2225 \pm 3 \mathrm{Ma}$ based on the overlying Hekpoort basalt (Fig. 4) ${ }^{38,40}$, which is within analytical uncertainty of the Yarrabubba impact event. Glacial diamictite deposits do not appear again in the geological record for $>400$ million 
years (Fig. 4) ${ }^{41,42}$. What caused the extended absence of glacial conditions after ca. $2225 \mathrm{Ma}$ is debated ${ }^{43}$. The end of the Palaeoproterozoic glaciations at $2225 \mathrm{Ma}$ occurred within an apparent $\sim 50 \mathrm{Myr}$ lull in global magmatism from 2266 to 2214 $\mathrm{Ma}^{44}$, making it difficult to appeal to volcanic outgassing as having played a significant role in forcing the glacial termination. Therefore, other mechanisms such as impact cratering need consideration. Radiometric age data presented here demonstrate synchronicity, within uncertainty, between the $2229 \pm 5 \mathrm{Ma}$ Yarrabubba impact event and the termination of glacial conditions (i.e. Rietfontein diamictite) at $2225 \pm 3 \mathrm{Ma}$. The geographic extent of the Rietfontein diamictite is poorly constrained, and it is not yet known if global glacial conditions existed at this time. Nonetheless, we apply numerical simulations below to explore the potential effects that a Yarrabubba-sized impact may have had on climactic conditions.

Several factors caused by the Yarrabubba impact event could have triggered a change in regional or global climate. Depending on the ambient climate state and palaeogeographic nature of the northern Yilgarn craton at the time of impact (e.g., ice cover, shallow ocean or carbonate platform overlying silicate basement), which is unknown, significant amounts of $\mathrm{CO}_{2}$, water vapour or other greenhouse gases could have been released into the relatively oxygen-poor Palaeoproterozoic atmosphere ${ }^{45}$ by the impact event. Given that the age of the Yarrabubba impact overlaps with the youngest Paleoproterozoic glacial deposits, we explore scenarios where the Yarrabubba impact site could have been covered by a continental ice sheet at the time of impact. Numerical models using the iSALE shock physics code ${ }^{46-48}$ (see Methods) demonstrate that the formation of a $70-\mathrm{km}$-diameter impact crater into a granitic target with an overlying ice sheet ranging from 2 to $5 \mathrm{~km}$ in thickness results in the almost instantaneous vaporisation of $95-240 \mathrm{~km}^{3}$ of ice and up to 5400 $\mathrm{km}^{3}$ total melting (Fig. 5). The vapourised ice corresponds to between $9 \times 10^{13}$ and $2 \times 10^{14} \mathrm{~kg}$ of water vapour being jetted into the upper atmosphere within moments of the impact (Fig. 5d). Impact-generated water vapour in the lower atmosphere would have condensed and rapidly precipitated as rain and snow with no significant long-term climate effects, or could have even triggered widespread glacial conditions via cloud albedo effects during interglacial periods ${ }^{49}$. However, ejection of high-altitude water vapour has potential for greenhouse radiative forcing, depending critically on atmospheric residence time ${ }^{50}$. Nonetheless, uncertainties in the structure and composition of Earth's Palaeoproterozoic upper atmosphere mean that the precise nature of atmospheric interactions of the collapsing vapour plume is inherently difficult to model ${ }^{50}$. Nevertheless, considering that Earth's atmosphere at the time of impact contained only a fraction of the current level of oxygen ${ }^{51}$, a possibility remains that the climatic forcing effects of $\mathrm{H}_{2} \mathrm{O}$ vapour released instantaneously into the atmosphere through a Yarrabubba-sized impact may have been globally significant. Understanding the residence times of impact-produced water vapour in a cold Palaeoproterozoic atmosphere, e.g. ref. ${ }^{50}$, and the complex interplay of radiative versus insulative effects of clouds, e.g. ref. ${ }^{52}$, during glacial conditions requires further investigation. The effects of impact cratering have long been recognised as drivers of climate change ${ }^{2,53}$. Many studies have described the atmospheric effects of the end-Cretaceous Chicxulub impact structure in Mexico $^{49,54,55}$, which resulted in global cooling of oceans and production of widespread acidic rains ${ }^{56,57}$. While the Yarrabubba structure dated at $2229 \pm 5$ Ma represents the Earth's oldest dated impact crater, its coincidence with termination of Palaeoproterozoic glacial conditions prompts further consideration of the ability of meteorite impacts to trigger climate change. a

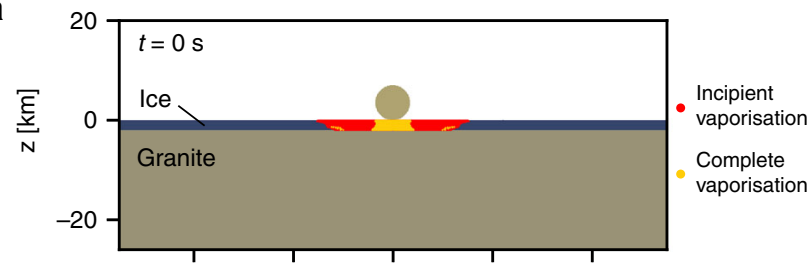

b
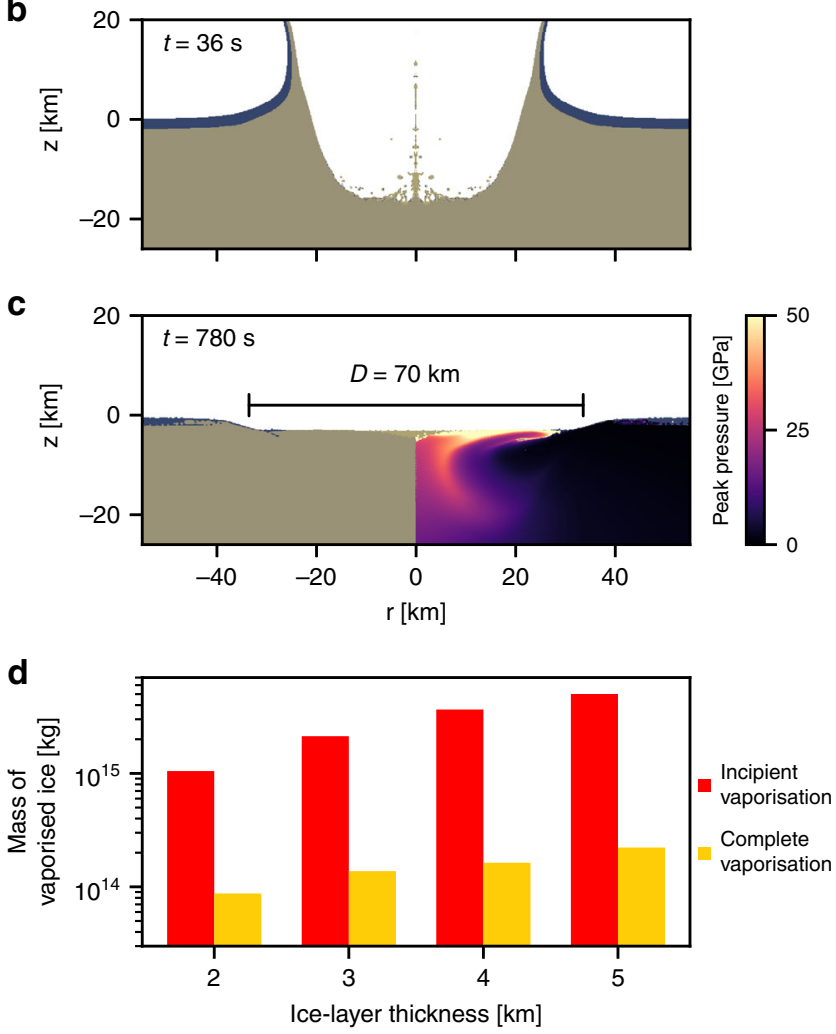

Fig. 5 Evolution of an impact crater in an ice covered continent.

Snapshots of the iSALE model with a 2-km-thick ice sheet showing a the initial conditions, $\mathbf{b}$ the transient crater and $\mathbf{c}$ the final crater. Superimposed on $\mathbf{a}$ is the initial position of tracer particles which were shock-heated to the critical entropy required to begin vaporisation (incipient vaporisation, red) and to completely vapourise ice (complete vaporisation, yellow). The colour scale on the right-hand side of $\mathbf{c}$ shows the peak shock pressure in the granite basement. $\mathbf{d}$ The calculated mass of ice shock-heated to the critical entropy for incipient and complete vaporisation, as a function of initial ice thickness. In each impact, the impactor size was $7 \mathrm{~km}$ and resulted in a final crater diameter of $\sim 70 \mathrm{~km}$.

\section{Methods}

Samples and preparation. Two samples from the Yarrabubba impact structure were selected for analysis (Fig. 1): a sample of the shocked Yarrabubba monzogranite (14YB07) and a sample from the Barlangi granophyre (14YB03). The Yarrabubba monzogranite was sampled from a small outcrop approximately 1.2 km WSW of Barlangi Rock. The Barlangi granophyre was sampled $2.7 \mathrm{~km} \mathrm{NNW}$ of Barlangi Rock from an apophyse intruding the Yarrabubba monzogranite along what appears to be a shallowly dipping fault plane or fracture.

Thin sections were prepared from each hand sample to allow petrographic characterisation of the lithological fabric and identification of shock features.

Zircon and monazite grains were separated from each sample. To separate zircon and monazite grains $\sim 1 \mathrm{~kg}$ splits of each sample were processed with a Selfrag electric pulse disaggregator in the John de Laeter Centre (JdLC), Curtin University, Western Australia. The heavy mineral fraction was then separated using the heavy liquid methylene iodide. Further concentration of zircon and monazite was achieved with a Frantz isodynamic magnetic separator. Grains were then handpicked and mounted in a $25.4 \mathrm{~mm}$ epoxy round. The epoxy rounds were given a mechanical polish to $1 \mu \mathrm{m}$ with diamond paste before a final

chemical-mechanical polish with a colloidal dispersion of $5 \mathrm{~nm}$ silica in $\mathrm{NaOH}$. 
After polishing, monazite and zircon grains were imaged using backscatter electron (BSE) atomic contrast imaging and cathodoluminescence (CL) imaging; images can be found in Supplementary Figs. 1-4. All scanning electron microscope (SEM) analyses were undertaken on the Tescan Mira3 field emission-gun (FEG) SEM at the Electron Microscopy Facility, within the JdLC. BSE photomicrographs were collected using an accelerating voltage of $15 \mathrm{kV}$, and CL images were collected with an accelerating voltage of $10 \mathrm{kV}$.

\section{Electron backscatter diffraction microstructural analyses. Shock-deformed} monazite and zircon grains were mapped by electron backscatter diffraction (EBSD). Electron backscatter patterns (EBSPs) were collected from the monazite and zircon in orthogonal grids using a Nordlys Nano high-resolution detector and Oxford Instruments Aztec 2.4 acquisition software package on the Mira3 FEGSEM. EBSD analyses were collected with a $20 \mathrm{kV}$ accelerating voltage, $70^{\circ}$ sample tilt, $\sim 20 \mathrm{~mm}$ working distance and $18 \mathrm{nA}$ beam current. EBSPs were collected with the following parameters; an acquisition speed of $\sim 40 \mathrm{~Hz}, 64$ frames were collected for a background noise subtraction, $4 \times 4$ binning, high gain, a Hough resolution of 60 and band detection $\min / \max$ of $6 / 8$. Maps were collected with a step size between 1.0 and $0.12 \mu \mathrm{m}$. Mean angular deviation values of the electron backscatter patterns for the maps ranged between 0.81 and 0.29 . Individual zircon grains were mapped using the match unit Zircon 5260 based on the unit cell parameters of Hazen et al. ${ }^{58}$ after the methods of Reddy et al. ${ }^{59}$. Monazite grains were mapped with the match unit described in ref. ${ }^{60}$, which originates from crystallographic data of ref. ${ }^{61}$. From the Yarrabubba monzogranite (14YB07) seven zircon and four monazite grains were analysed, while eight zircon and seven monazite grains were analysed from the Barlangi granophyre (14YB03).

Post-processing the EBSD data was undertaken with Oxford Instruments Channel 5.11 software suite. All EBSD data were given a wild-spike noise reduction and a six nearest neighbour zero-solution correction. EBSD maps were produced using the Tango suite of Channel 5, while pole figures were processed in the Mambo suite of Channel5. EBSD maps and pole figures (as equal area, lower hemisphere projections) of the shocked monazite and zircons can be found in Supplementary Figs. 1-4. Using Tango the following maps were produced for the shocked zircon and monazite grains:

(1) Inverse pole figure (IPF) maps of crystallographic orientations of zircon (Fig. 2a, c).

(2) All Euler crystallographic orientation map of shocked monazite (Fig. 2b, d).

(3) Grain misorientation map, using the grain rotation orientation direction (GROD)-angle function of Channel5, which helps visualise the substructure of the grains by plotting the deviation angle of each pixel from the mean grain orientation, grain boundaries are defined as $>10^{\circ}$. Blue domains are low strains, while warm colours represent higher degrees of misorientation (Supplementary Figs. 1-4).

\section{Secondary ion mass spectrometry $\mathbf{U}-\mathbf{P b}$ age analyses. Following EBSD map-} ping of monazite and zircon, in situ $\mathrm{U}-\mathrm{Th}-\mathrm{Pb}$ isotopic measurements targeting specific shock microstructural domains were carried out using the SHRIMP-II secondary ion mass spectrometer (SIMS) at the JdLC. Operating procedures for uranium, thorium and lead isotopic measurements on zircon are based on those described by Compston et al. ${ }^{62}$ and Claoué-Long et al. ${ }^{63}$, with modifications summarised by Williams ${ }^{64}$. SHRIMP U-Pb zircon and monazite data are reduced using SQUID 2.50 and Isoplot 3.71 (add-ins for Microsoft Excel65,66) with decay constants recommended by Steiger and Jäger ${ }^{67}$. Ratios of ${ }^{206} \mathrm{~Pb}^{+} / 238 \mathrm{U}^{+}$in zircon are calibrated to the known ${ }^{206} \mathrm{~Pb} /{ }^{238} \mathrm{U}$ of the zircon standard, using a power-law relationship between ${ }^{206} \mathrm{~Pb}^{+} / 238 \mathrm{U}^{+}$and $\mathrm{UO}^{+} / \mathrm{U}^{+}$, with a fixed exponent of 2.0 (determined empirically from measurements of zircon standards over several years $\left.{ }^{63}\right)$. All zircon analyses were run during one session and were standardised with primary zircon reference material BR266 $\left(559 \mathrm{Ma},{ }^{206} \mathrm{~Pb} /{ }^{238} \mathrm{U}=0.09059\left(\right.\right.$ ref. $\left.{ }^{68}\right)$ ) and concentration reference Temora $\left(416.8 \mathrm{Ma},{ }^{206} \mathrm{~Pb} /{ }^{238} \mathrm{U}=0.06683\right.$ (ref. $\left.{ }^{69}\right)$ ). Archaean zircon reference OGC $\left(3465 \mathrm{Ma},{ }^{207} \mathrm{~Pb} / 206 \mathrm{~Pb}=0.29907\right.$ (ref. $\left.\left.{ }^{70}\right)\right)$ was analysed during the session to check for ${ }^{207} \mathrm{~Pb} /{ }^{206} \mathrm{~Pb}$ fractionation. $\mathrm{No}{ }^{207} \mathrm{~Pb} /{ }^{206} \mathrm{~Pb}$ fractionation correction was deemed necessary. Eight analyses of the BR266 standard were obtained during the session which indicated an external spot-to-spot (reproducibility) uncertainty of $1.42 \%(1 \sigma)$ and a ${ }^{238} \mathrm{U}^{206} \mathrm{~Pb}^{*}$ calibration uncertainty of $0.54 \%(1 \sigma)$. Calibration uncertainties are included in the errors of ${ }^{238} \mathrm{U}^{206} \mathrm{~Pb}^{*}$ ratios and dates listed in Supplementary Table 1. Common $\mathrm{Pb}$ corrections were applied to all analyses using contemporaneous isotopic compositions determined according to the model of Stacey and Kramers ${ }^{71}$.

Detailed SHRIMP operating procedures for monazite are outlined in Foster et al..$^{72}$ and Wingate and Kirkland ${ }^{73}$. A $\sim 10 \mu \mathrm{m}$ diameter primary beam was employed with an intensity of $\sim 0.5 \mathrm{nA}$. Ion microprobe analyses of monazite are affected by an uneven background spectrum of scattered ions ${ }^{74}$, which can be reduced effectively by use of the SHRIMP retardation lens system, which is set at $\sim 10 \mathrm{kV}$. This discriminates against low-energy ions entering the collector. Each analysis consists of six cycles through the isotopic masses in the following sequence: 202 (species $\left[{ }^{139} \mathrm{La}^{31} \mathrm{P}^{16} \mathrm{O}_{2}\right]+$, count time $2 \mathrm{~s}$ ), $203\left(\left[{ }^{140} \mathrm{Ce}^{31} \mathrm{P}^{16} \mathrm{O}_{2}\right]+\right.$, 2 s), $204(204 \mathrm{~Pb}+, 10 \mathrm{~s}), 204.1$ (background, $10 \mathrm{~s}), 206(206 \mathrm{~Pb}+, 10 \mathrm{~s}), 207\left({ }^{207} \mathrm{~Pb}+\right.$ $30 \mathrm{~s}), 208\left({ }^{208} \mathrm{~Pb}+, 5 \mathrm{~s}\right), 232\left({ }^{232} \mathrm{Th}+, 5 \mathrm{~s}\right), 254\left(\left[{ }^{238} \mathrm{U}^{16} \mathrm{O}_{2}\right]+, 5 \mathrm{~s}\right), 264$ $\left(\left[{ }^{232} \mathrm{Th}^{16} \mathrm{O}_{2}\right]+, 2 \mathrm{~s}\right)$ and $270\left(\left[{ }^{238} \mathrm{U}^{16} \mathrm{O}_{2}\right]+, 3 \mathrm{~s}\right)$. The monazite standard "India" was used for concentration calibration $\left(509 \mathrm{Ma} 2890 \mathrm{ppm}{ }^{238} \mathrm{U}^{74}\right)$ and also U-Pb calibration. Ratios of ${ }^{206} \mathrm{~Pb}+/{ }^{238} \mathrm{U}+$ in monazite are calibrated to the known ${ }^{206} \mathrm{~Pb} / 238 \mathrm{U}$ of the monazite standard using a linear relationship between ${ }^{206} \mathrm{~Pb}$ $+/ \mathrm{UO}_{2}+$ and $\mathrm{UO}+/ \mathrm{UO}_{2}+{ }^{74}$. Monazite generates an unresolvable isobaric interference on ${ }^{204} \mathrm{~Pb}+$, which may be $\left({ }^{232} \mathrm{Th}^{144} \mathrm{Nd}^{16} \mathrm{O}_{2}\right)++{ }^{75,76}$. This interference has been observed to correlate with thorium content ${ }^{74}$. Excess ${ }^{204} \mathrm{~Pb}+$ counts are corrected against the India monazite standard assuming ${ }^{206} \mathrm{~Pb} /{ }^{238} \mathrm{U}-207 \mathrm{~Pb} / 235 \mathrm{U}$ age-concordance of the standard at a known thorium concentration. Fractionation of the ${ }^{207} \mathrm{~Pb} /{ }^{206} \mathrm{~Pb}$ ratio is typically observed when the retardation lens system is at operating voltage during monazite analysis. Fractionation of the ${ }^{207} \mathrm{~Pb} / 206 \mathrm{~Pb}$ ratio is monitored and corrections were applied, if necessary, by reference to the GM3 monazite standard ${ }^{77}$ which was run as an unknown. Uncertainties associated with this correction are added in quadrature to the uncertainties of ${ }^{207} \mathrm{~Pb}^{*} / 206 \mathrm{~Pb}^{*}$ ratios and dates. The common- $\mathrm{Pb}$ correction was based on measured ${ }^{204} \mathrm{~Pb}$ and Stacey and Kramers ${ }^{71}$ crustal $\mathrm{Pb}$ composition appropriate for the age of the sample. Data were reduced using SQUID 2 software and plotted using Isoplot 3.66 (ref. ${ }^{66}$ ).

Nine SHRIMP analyses from 7 zircon grains and 16 SHRIMP analyses from four monazite grains were collected from the sample of the Yarrabubba monzogranite 14YB07. Nineteen SHIRMP analyses from 8 zircon grains and 19 SHRIMP analyses from 7 monazite grains were collected from the sample of the Barlangi granophyre 14YB03. Selection criteria for the analytical spots were based on the EBSD data, and both the strained domains and the strain-free neoblastic domains of the shocked monazite and zircon were targeted.

$\mathrm{U}-\mathrm{Pb}$ isotopic data are provided in Supplementary Tables 1 and 2; uncertainties given for individual analyses in the tables (ratios and ages) are at the $1 \sigma$ level. Terra-Wasserburg concordia plots with $2 \sigma$ error ellipses for all analyses are shown in Fig. 2. Age uncertainties cited in the text are at the $2 \sigma$ level. SHRIMP analytical pit locations are documented in Supplementary Figs. 1-4.

Hydrocode impact simulations. To better constrain the environmental effects of a Yarrabubba-sized impact structure into a continental ice sheet, the formation of various impact craters were computed using the iSALE shock physics code ${ }^{46-48}$, which is based on the original SALE algorithm ${ }^{78}$. The initial conditions were a granitic target covered by an ice sheet of varying thickness $(2-5 \mathrm{~km})$. For all ice thicknesses considered here, an impactor diameter of $7 \mathrm{~km}$ produced a final crater of $\sim 70 \mathrm{~km}$ diameter. The impactor was prescribed an impact velocity of $17 \mathrm{~km} / \mathrm{s}$, the current best estimate for the average speed of bolides striking Earth. The ANEOS equation of state for granite ${ }^{79}$ was used to model both the impactor and the granitic target and the 5-phase SESAME equation of state for ice ${ }^{80}$ was used to model the overlying ice sheet. A computational cell size of $125 \mathrm{~m}$ was used, resulting in a resolution of 28 cells per projectile radius. The end product was an impact crater with a $\sim 70 \mathrm{~km}$ diameter impact structure, with a zone $40-50 \mathrm{~km}$ in diameter in the granite that experienced high shock pressures $(>50 \mathrm{GPa})$ and is heavily fractured, which in some simulations produces an uplifted region. The mass of ice that vapourised during the impact was determined by comparing the entropy of Lagrangian tracer particles in the ice sheet to the critical entropy for incipient (entropy required to go to liquid and vapour state) and complete vaporisation (entropy required to go to a completely vapour state) for ice. In the model with a 2 $\mathrm{km}$ thick ice sheet, $1.0 \times 10^{15} \mathrm{~kg}$ of $\mathrm{H}_{2} \mathrm{O}$ was above the critical entropy for incipient vaporisation, and $8.7 \times 10^{13} \mathrm{~kg}$ of $\mathrm{H}_{2} \mathrm{O}$ was completely vapourised. The mass of ice vapourised in each scenario with different ice thicknesses can be seen in Fig. $5 \mathrm{~d}$. Snapshots of the iSALE model at time 0, 36 and $780 \mathrm{~s}$ can be found in Fig. 5 .

\section{Data availability}

All data used in this manuscript are included in the Supplementary Information file. For access to geologic specimens contact author T.M.E.

\section{Code availability}

The Isoplot and Squid programs used for $\mathrm{U}-\mathrm{Pb}$ data processing are available through the Berkley Geochronology Center http://www.bgc.org. iSALE is a widely used shock physics code distributed to registered academic non-commercial users via a GitHub repository. Scientists interested in using or developing iSALE should see http://www.isale-code.de for a description of application requirements.

Received: 12 March 2019; Accepted: 11 December 2019; Published online: 21 January 2020

\section{References}

1. Abramov, O. \& Mojzsis, S. J. Microbial habitability of the Hadean Earth during the late heavy bombardment. Nature 459, 419 (2009).

2. Kring, D. A. Environmental consequences of impact cratering events as a function of ambient conditions on Earth. Astrobiology 3, 133-152 (2003).

3. Hergarten, S. \& Kenkmann, T. The number of impact craters on Earth: any room for further discoveries? Earth Planet. Sci. Lett. 425, 187-192 (2015). 
4. Grieve, R. A. F. \& Pesonen, L. J. The terrestrial impact cratering record. Tectonophysics 216, 1-30 (1992).

5. McEwen, A. S., Moore, J. M. \& Shoemaker, E. M. The Phanerozoic impact cratering rate: evidence from the farside of the Moon. J. Geophys. Res. Planets 102, 9231-9242 (1997).

6. Byerly, G. R., Lowe, D. R., Wooden, J. L. \& Xie, X. An archean impact layer from the Pilbara and Kaapvaal cratons. Science 297, 1325-1327 (2002).

7. Hassler, S. W., Simonson, B. M., Sumner, D. Y. \& Bodin, L. Paraburdoo spherule layer (Hamersley Basin, Western Australia): distal ejecta from a fourth large impact near the Archean-Proterozoic boundary. Geology 39, 307-310 (2011).

8. Kamo, S. L., Reimold, W. U., Krogh, T. E. \& Colliston, W. P. A 2.023 Ga age for the Vredefort impact event and a first report of shock metamorphosed zircons in pseudotachylitic breccias and Granophyre. Earth Planet. Sci. Lett. 144, 369-387 (1996).

9. Moser, D. E. Dating the shock wave and thermal imprint of the giant Vredefort impact, South Africa. Geology 25, 7-10 (1997).

10. Krogh, T., Davis, D. W. \& Corfu, F. in The Geology and Ore Deposits of the Sudbury Structure, Ontario (eds Pye, E. G., Naldrett, A. J. \& Giblin, P. E.) 431-447 (Ontario Geological Survey, 1984).

11. Pati, J. K. et al. Geochemical evidence of an extraterrestrial component in impact melt breccia from the Paleoproterozoic Dhala impact structure, India. Meteorit. Planet. Sci. 52, 722-736 (2017).

12. Reimold, W. U., Ferrière, L., Deutsch, A. \& Koeberl, C. Impact controversies: impact recognition criteria and related issues. Meteorit. Planet. Sci. 49, 723-731 (2014).

13. Mashchak, M. S. \& Naumov, M. V. The Suavjärvi impact structure, NW Russia. Meteorit. Planet. Sci. 47, 1644-1658 (2012).

14. Schulte, P. et al. The Chicxulub asteroid impact and mass extinction at the Cretaceous-Paleogene boundary. Science 327, 1214-1218 (2010).

15. Burgess, S. Deciphering mass extinction triggers. Science 363, 815-816 (2019).

16. Hoffman, P. F. The great oxidation and a Siderian snowball Earth: MIF-S based correlation of Paleoproterozoic glacial epochs. Chem. Geol. 362, 143-156 (2013).

17. Kirschvink, J. L. et al. Paleoproterozoic snowball Earth: extreme climatic and geochemical global change and its biological consequences. Proc. Natl Acad. Sci. USA 97, 1400-1405 (2000).

18. Macdonald, F. A., Bunting, J. A. \& Cina, S. E. Yarrabubba-a large, deeply eroded impact structure in the Yilgarn Craton, Western Australia. Earth Planet. Sci. Lett. 213, 235-247 (2003).

19. Therriault, A. M., Grieve, R. A. F. \& Reimold, W. U. Original size of the Vredefort Structure: implications for the geological evolution of the Witwatersrand Basin. Meteorit. Planet. Sci. 32, 71-77 (1997).

20. Wang, X.-C., Li, Z.-X., Li, J., Pisarevsky, S. A. \& Wingate, M. T. D. Genesis of the $1.21 \mathrm{Ga}$ Marnda Moorn large igneous province by plume-lithosphere interaction. Precambrian Res. 241, 85-103 (2014).

21. Wingate, M. T. D., Pirajno, F. \& Morris, P. A. Warakurna large igneous province: a new Mesoproterozoic large igneous province in west-central Australia. Geology 32, 105-108 (2004).

22. Tingey, R. J. Sanston, Western Australia, 1:250,000 Geological SeriesExplantatory Notes (Bureau of Mineral Resources, Geology and Geophysics, Canberra, 1985).

23. Cupelli, C. L. et al. Discovery of mafic impact melt in the center of the Vredefort dome: archetype for continental residua of early Earth cratering? Geology 42, 403-406 (2014).

24. Fletcher, I. R. \& McNaughton, N. J. in Characterisation and Metallogenic Significance of Archaean Granitoids of the Yilgarn Craton, Western Australia, Report 222 (eds Whitaker, A. et al.) (Minerals and Energy Research Institute of Western Australia, 2001).

25. Nelson, D. R.. in Compilation of Geochronology Data, June 2006 Update (Western Australia Geological Survey, 2005).

26. Pirajno, F. Hydrothermal processes associated with meteorite impact structures: evidence from three Australian examples and implications for economic resources. Aust. J. Earth Sci. 52, 587-605 (2005).

27. Cavosie, A. J. et al. A terrestrial perspective on using ex situ shocked zircons to date lunar impacts. Geology 43, 999-1002 (2015).

28. Erickson, T. M. et al. Shocked monazite chronometry: integrating microstructural and in situ isotopic age data for determining precise impact ages. Contrib. Mineral. Petrol. 172, https://doi.org/10.1007/s00410-017-1328-2 (2017).

29. Kenny, G. G., Morales, L. F., Whitehouse, M. J., Petrus, J. A. \& Kamber, B. S. The formation of large neoblasts in shocked zircon and their utility in dating impacts. Geology 45, 1003-1006 (2017).

30. Erickson, T. M., Cavosie, A. J., Moser, D. E., Barker, I. R. \& Radovan, H. A. Correlating planar microstructures in shocked zircon from the Vredefort Dome at multiple scales: crystallographic modeling, external and internal imaging, and EBSD structural analysis. Am. Mineralogist 98, 53-65 (2013).

31. Moser, D. E. et al. New zircon shock phenomena and their use for dating and reconstruction of large impact structures revealed by electron nanobeam
(EBSD, CL, EDS) and isotopic U-Pb and (U-Th)/He analysis of the Vredefort dome. Can. J. Earth Sci. 48, 117-139 (2011)

32. Timms, N. E. et al. Resolution of impact-related microstructures in lunar zircon: a shock-deformation mechanism map. Meteorit. Planet. Sci. 47, 120-141 (2012)

33. Erickson, T. M., Cavosie, A. J., Pearce, M. A., Timms, N. E. \& Reddy, S. M. Empirical constraints on shock features in monazite using shocked zircon inclusions. Geology 44, 635-638 (2016).

34. Timms, N. E. et al. A pressure-temperature phase diagram for zircon at extreme conditions. Earth Sci. Rev. 165, 185-202 (2017).

35. Cavosie, A. J., Timms, N. E., Erickson, T. M., Hagerty, J. J. \& Hörz, F. Transformations to granular zircon revealed: twinning, reidite, and $\mathrm{ZrO}_{2}$ in shocked zircon from Meteor Crater (Arizona, USA). Geology 44, 703-706 (2016).

36. Erickson, T. M. et al. Microstructural constraints on the mechanisms of the transformation to reidite in naturally shocked zircon. Contrib. Mineral. Petrol. 172, https://doi.org/10.1007/s00410-016-1322-0 (2017).

37. Timms, N. E. et al. Cubic zirconia in $>2370^{\circ} \mathrm{C}$ impact melt records Earth's hottest crust. Earth Planet. Sci. Lett. 477, 52-58 (2017).

38. Gumsley, A. P. et al. Timing and tempo of the Great Oxidation Event. Proc. Natl Acad. Sci. USA 114, 1811-1816 (2017).

39. Evans, D. A., Beukes, N. J. \& Kirschvink, J. L. Low-latitude glaciation in the Palaeoproterozoic era. Nature 386, 262 (1997).

40. Dorland, H. C. Provenance ages and timing of sedimentation of selected Neoarchean and Paleoproterozoic successions on the Kaapvaal Craton Ph.D. thesis, Rand Afrikaans University (2004).

41. Eyles, N. Glacio-epochs and the supercontinent cycle after $\sim 3.0 \mathrm{Ga}$ : Tectonic boundary conditions for glaciation. Palaeogeogr. Palaeoclimatol. Palaeoecol. 258, 89-129 (2008).

42. Williams, G. E. Subglacial meltwater channels and glaciofluvial deposits in the Kimberley Basin, Western Australia: 1.8 Ga low-latitude glaciation coeval with continental assembly. J. Geol. Soc. 162, 111-124 (2005).

43. Kopp, R. E., Kirschvink, J. L., Hilburn, I. A. \& Nash, C. Z. The Paleoproterozoic snowball Earth: a climate disaster triggered by the evolution of oxygenic photosynthesis. Proc. Natl Acad. Sci. USA 102, 11131-11136 (2005).

44. Spencer, C. J., Murphy, J. B., Kirkland, C. L., Liu, Y. \& Mitchell, R. N. A palaeoproterozoic tectono-magmatic lull as a potential trigger for the supercontinent cycle. Nat. Geosci. 11, 97-101 (2018).

45. Soden, B. J., Jackson, D. L., Ramaswamy, V., Schwarzkopf, M. D. \& Huang, X. The radiative signature of upper tropospheric moistening. Science $\mathbf{3 1 0}$, 841-844 (2005)

46. Collins, G. S. et al. iSALE: a multi-material, multi-rheology shock physics code for simulating impact phenomena in two and three dimensions. $\mathrm{m} 9$. figshare.3473690 (2016)

47. Collins, G. S., Melosh, H. J. \& Ivanov, B. A. Modeling damage and deformation in impact simulations. Meteorit. Planet. Sci. 39, 217-231 (2004).

48. Wünnemann, K., Collins, G. S. \& Melosh, H. J. A strain-based porosity model for use in hydrocode simulations of impacts and implications for transient crater growth in porous targets. Icarus 180, 514-527 (2006).

49. Bendtsen, J. \& Bjerrum, C. J. Vulnerability of climate on Earth to sudden changes in insolation. Geophys. Res. Lett. 29, 1-4 (2002).

50. Koeberl, C. \& Ivanov, B. A. Asteroid impact effects on Snowball Earth. Meteorit. Planet. Sci. 54, 2273-2285 (2019).

51. Lyons, T. W., Reinhard, C. T. \& Planavsky, N. J. The rise of oxygen in Earth's early ocean and atmosphere. Nature 506, 307 (2014).

52. Hoffman, P. F. et al. Snowball Earth climate dynamics and Cryogenian geology-geobiology. Sci. Adv. 3, e1600983 (2017).

53. Ivanov, B. in Catastrophic Events Caused by Cosmic Objects (eds Adushkin, V. \& Nemchinov, I.) 163-205 (Springer, Netherlands, 2008).

54. Pierazzo, E., Hahmann, A. N. \& Sloan, L. C. Chicxulub and climate: radiative perturbations of impact-produced S-bearing gases. Astrobiology 3, 99-118 (2003).

55. Toon, O. B., Zahnle, K., Morrison, D., Turco, R. P. \& Covey, C. Environmenta perturbations caused by the impacts of asteroids and comets. Rev. Geophys. 35, 41-78 (1997).

56. Artemieva, N., Morgan, J. \& Party, E. S. Quantifying the release of climateactive gases by large meteorite impacts with a case study of Chicxulub. Geophys. Res. Lett. 44, 180-110,188 (2017).

57. MacLeod, K. G., Quinton, P. C., Sepúlveda, J. \& Negra, M. H. Postimpact earliest Paleogene warming shown by fish debris oxygen isotopes (El Kef, Tunisia). Science 360, 1467-1469 (2018).

58. Hazen, R. M. \& Finger, L. W. Crystal structure and compressibilty of zircon at high pressure. Am. Mineral. 64, 196-201 (1979).

59. Reddy, S. M., Timms, N. E., Pantleon, W. \& Trimby, P. Quantitative characterization of plastic deformation of zircon and geological implications. Contrib. Mineral. Petrol. 153, 625-645 (2007). 
60. Erickson, T. M. et al. Deformed monazite yields high-temperature tectonic ages. Geology 43, 383-386 (2015)

61. Ni, Y., Hughes, J. M. \& Mariano, A. N. Crystal chemistry of the monazite and xenotime structures. Am. Mineral. 80, 21-26 (1995).

62. Compston, W., Williams, I. S. \& Meyer, C. U-Pb geochronology of zircons from lunar breccia 73217 using a sensitive high mass-resolution ion microprobe. J. Geophys. Res. Solid Earth 89, B525-B534 (1984).

63. Claoué-Long, J. C., Compston, W., Roberts, J. \& Fanning, C. M. Two Carboniferous ages: a comparison of SHRIMP zircon dating with conventional zircon ages and 40Ar/39Ar analysis in Geochronology Time Scales and Global Stratigraphic Correlation Vol. 54 (eds Berggren, W. A., Kent, D. V., Aubrey, M.-P. \& Hardenbol, J.) 3-21 (SEPM (Society for Sedimentary Geology), 1995).

64. Williams, I. S. U-Th-Pb Geochronology by Ion Microprobe in Applications of Microanalytical Techniques to Understanding Mineralizing Processes Vol. 7 (eds McKibben, M. A., Shanks III, W. C. \& Ridley, W. I.) 1-35 (Society of Economic Geologists, 1998).

65. Ludwig, K. User's Manual for Isoplot 3.00: A Geochronological Toolkit for Microsoft Excel (Kenneth R. Ludwig, 2003).

66. Ludwig, K. R. Squid 1.03A User's Manual. Vol. 2 (Berkely Geochronology Center, 2001).

67. Steiger, R. H. \& Jäger, E. Subcommission on geochronology: convention on the use of decay constants in geo- and cosmochronology. Earth Planet. Sci. Lett. 36, 359-362 (1977).

68. Stern, R. A new isotopic and trace-element standard for the ion microprobe: Preliminary thermal ionisation mass spectrometry (TIMS) $\mathrm{U}-\mathrm{Pb}$ and electronmicroprobe data in Current Research 2001-F (Geological Survey of Canada, 2001).

69. Black, L. P. et al. Improved $206 \mathrm{~Pb} / 238 \mathrm{U}$ microprobe geochronology by the monitoring of a trace-element-related matrix effect; SHRIMP, ID-TIMS, ELA-ICP-MS and oxygen isotope documentation for a series of zircon standards. Chem. Geol. 205, 115-140 (2004).

70. Stern, R. A. An introduction to secondary ion mass spectrometry (SIMS) in geology in Secondary Ion Mass Spectrometry in the Earth Sciences: Gleaning the Big Picture from a Small Spot (ed Mostafa Fayek) Ch. 1, 1-18 (Mineralogical Association of Canada, 2009).

71. Stacey, J. S. \& Kramers, J. D. Approximation of terrestrial lead isotope evolution by a two-stage model. Earth Planet. Sci. Lett. 26, 207-221 (1975).

72. Foster, G., Kinny, P., Vance, D., Prince, C. \& Harris, N. The significance of monazite $\mathrm{U}-\mathrm{Th}-\mathrm{Pb}$ age data in metamorphic assemblages; a combined study of monazite and garnet chronometry. Earth Planet. Sci. Lett. 181, 327-340 (2000).

73. Wingate, M. T. D. \& Kirkland, C. L. Introduction to Geochronology Information Released in 2012, 5 (Geological Survey of Western Ausralia, 2012).

74. Kinny, P. D. Users' Guide to U-Th-Pb Dating of Titanite, Perovskite, Monazite and Baddeleyite Using the W.A. SHRIMP. 1-21 (School of Physical Sciences, Curtin University, 1997).

75. Kirkland, C. L., Whitehouse, M. J. \& Slagstad, T. Fluid-assisted zircon and monazite growth within a shear zone: a case study from Finnmark, Arctic Norway. Contrib. Mineral. Petrol. 158, 637-657 (2009).

76. Ireland, T., Wooden, J., Persing, H. \& Ito, B. J. E. Geological applications and analytical development of the SHRIMP-RG. EOS Trans. Am. Geophys. Union 80, F1117 (1999).

77. Kennedy, A. \& Kinny, P. Identifying inter-and intra-laboratory SIMS Monazite standards in SHRIMP Workshop, Hiroshima, Japan. 11-14 (2004).

78. Amsden, A. A., Ruppel, H. M. \& Hirt, C. W. SALE: A Simplified ALE Computer Program for Fluid Flow at all Speeds. 105 (United States, 1980).

79. Pierazzo, E., Vickery, A. M. \& Melosh, H. J. A reevaluation of impact melt production. Icarus 127, 408-423 (1997).

80. Senft, L. E. \& Stewart, S. T. Impact crater formation in icy layered terrains on Mars. Meteorit. Planet. Sci. 43, 1993-2013 (2008).
81. CITIC Nickel Australia Pty Ltd. Yarrabubba 70182. http://geodownloads.dmp. wa.gov.au/downloads/geophysics/70182.zip (2005).

82. Melezhik, V. A. et al. Emergence of the aerobic biosphere during the ArcheanProterozoic transition: challenges of future research. GSA Today 15, 4-11 (2005).

83. Martin, A. P., Condon, D. J., Prave, A. R. \& Lepland, A. A review of temporal constraints for the Palaeoproterozoic large, positive carbonate carbon isotope excursion (the Lomagundi-Jatuli Event). Earth Sci. Rev. 127, 242-261 (2013)

\section{Acknowledgements}

T.M.E. would like to thank the Geological Society of Australia, Western Australia Division, for supporting fieldwork at Yarrabubba. E. Thern is thanked for assistance during fieldwork, and D. Kring and M. Schmieder are thanked for fruitful conversations. The ARC, Curtin University, University of Western Australia and CSIRO are acknowledged for funding the Tescan Mira3 FEG-SEM (ARC LE130100053) and the SHRIMP-II housed in the John De Laeter Centre, Curtin University. We thank the developers of iSALE (isale-code.de). T.M.D. was supported by STFC grant ST/S000615/1

\section{Author contributions}

T.M.E. designed and undertook all experiments, N.E.T. and A.J.C. assisted with EBSD data processing, C.L.K. collected and processed all SHRIMP data, and T.M.D. undertook all iSALE impact modelling simulations. All authors were involved in the production of this manuscript.

\section{Competing interests}

The authors declare no competing interests.

\section{Additional information}

Supplementary information is available for this paper at https://doi.org/10.1038/s41467 019-13985-7.

Correspondence and requests for materials should be addressed to T.M.E.

Peer review information Nature Communications thanks Paul Hoffman, Francis Macdonald and the other, anonymous, reviewer(s) for their contribution to the peer review of this work. Peer reviewer reports are available.

Reprints and permission information is available at http://www.nature.com/reprints

Publisher's note Springer Nature remains neutral with regard to jurisdictional claims in published maps and institutional affiliations.

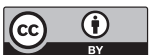

Open Access This article is licensed under a Creative Commons Attribution 4.0 International License, which permits use, sharing adaptation, distribution and reproduction in any medium or format, as long as you give appropriate credit to the original author(s) and the source, provide a link to the Creative Commons license, and indicate if changes were made. The images or other third party material in this article are included in the article's Creative Commons license, unless indicated otherwise in a credit line to the material. If material is not included in the article's Creative Commons license and your intended use is not permitted by statutory regulation or exceeds the permitted use, you will need to obtain permission directly from the copyright holder. To view a copy of this license, visit http://creativecommons.org/ licenses/by/4.0/.

This is a U.S. government work and not under copyright protection in the U.S.; foreign copyright protection may apply 2020 